
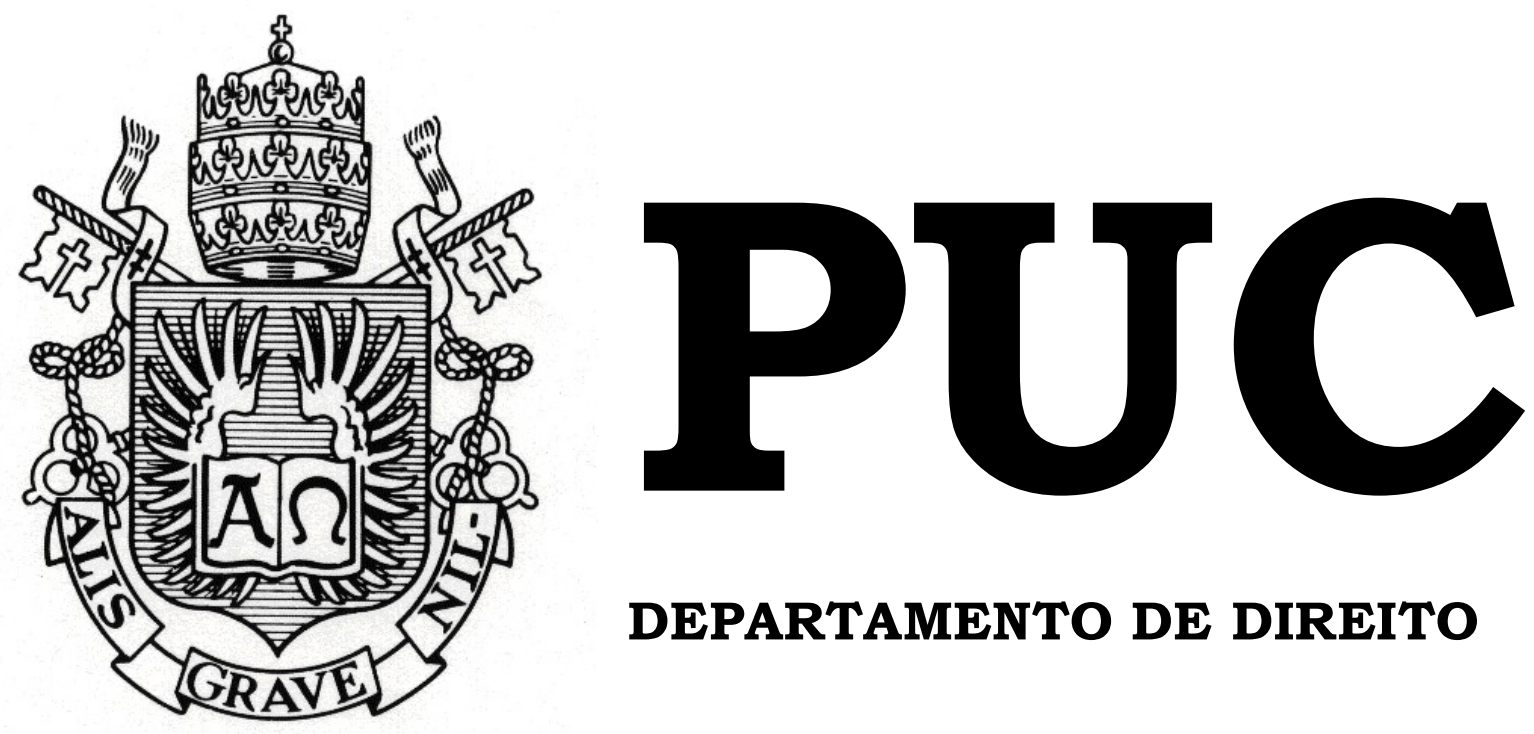

DEPARTAMENTO DE DIREITO

\title{
SERVIDÃO, LIBERDADE E ORGANIZAÇÃO POLÍTICA NA FILOSOFIA DE LA BOÉTIE E ESPINOSA
} por

CECÍLIA ALKIMIN VIEIRA

ORIENTADOR (A): FRANCISCO DE GUIMARAENS 2018.2

PONTIFÍCIA UNIVERSIDADE CATÓLICA DO RIO DE JANEIRO RUA MARQUÊS DE SÃO VICENTE, 225 - CEP 22453-900 RIO DE JANEIRO - BRASIL 


\title{
SERVIDÃO, LIBERDADE E ORGANIZAÇÃO POLÍTICA NA FILOSOFIA DE LA BOÉTIE E ESPINOSA
}

\author{
Por
}

\section{CECÍLIA ALKIMIN VIEIRA}

Monografia

apresentada

ao

Departamento de Direito da Pontifícia Universidade Católica do Rio de Janeiro (PUC-Rio) para a obtenção do Título de Bacharel em Direito.

Orientador

(a):

Francisco

de

Guimaraens 
Todas as revoluções

Que eu desejo

Começam em mim

Ryane Leão 


\section{Agradecimentos}

A minha avó Dione, in memoriam, uma grande mulher oprimida pela sociedade de seu tempo. Não pôde viver tudo o que sonhou, e viu em mim a oportunidade de se realizar. Infelizmente, não viveu o bastante para ver a minha primeira grande conquista, mas estará sempre nas minhas lembranças nos momentos mais importantes.

Ao Vicente, meu grande companheiro, sem o qual trilhar o caminho para a vida adulta não seria o mesmo. De todos os encontros da vida, o melhor deles.

Aos meus pais, Fernando e Martha, pelo exemplo de luta, perseverança e dedicação, por todo carinho, amor e conhecimento que me foi dado. Crescer com pais tão especiais e inspiradores tem sido uma grande jornada de aprendizado.

As minhas tias, Fernanda e Adriana, meus maiores exemplos, tão diferentes e, ainda assim, tão importantes nas minhas escolhas profissionais. Fonte de inspiração da advogada que desejo ser um dia.

A toda minha família, pelo incentivo e carinho que nunca me faltaram.

Ao Francisco de Guimaraens, o Chico, meu orientador e mestre. Eu deveria dizer que lhe devo muito da minha formação, mas se bem o conheço, sua resposta seria de que toda dívida pressupõe uma tristeza, que nada tem a ver com nossa história. Então, fica aqui meu agradecimento, por nunca ter desistido de mim.

As grandes professoras que tive na PUC-Rio, Thamis Dalsenter, Thula Pires, Inês Alegria, Aline Valverde e Regina Coeli. Exemplos de mulheres e profissionais, me ensinaram a não esmorecer diante de um meio acadêmico tão machista quanto o do Direito.

Ao professor Maurício Rocha e seu grupo de estudos sobre Espinosa, pela disponibilidade de ensinar e por ter me proporcionado a oportunidade de estar mais próxima da filosofia espinosana. 
Aos funcionários e funcionárias do Departamento de Direito da PUC-Rio, em especial, Sebastião, Neto e Marcos, pela gentileza habitual e toda ajuda que me deram ao longo da graduação.

Aos meus grandes amigos e amigas de Escola Parque, com os quais tive a sorte de viver os melhores momentos da minha vida, por me ensinarem que, ainda que nossos caminhos sejam diferentes, a amizade permanece a mesma. 


\section{Resumo}

VIEIRA, Cecília Alkimin; GUIMARAENS, Francisco de. A organização política servil: sua construção a partir do conceito de servidão voluntária em La Boétie e Espinosa. Rio de Janeiro, 2018, 45 p. Trabalho de conclusão de curso. Departamento de Direito, Pontifícia Universidade Católica do Rio de Janeiro.

La Boétie apresenta o conceito de servidão voluntária para explicar as razões pelas quais certos povos se sujeitam aos desmandos de governantes autoritários. Neste trabalho, busca-se analisar o referido conceito, bem como o entendimento de Espinosa também sobre as causas e consequências da servidão. Para isso, é necessário analisar, ainda que brevemente, o que Espinosa entende pelos conceitos de afeto, paixão, liberdade, potência e desejo. Assim, será possível traçar paralelos entre as filosofias de ambos os autores, La Boétie e Espinosa, acerca da servidão que assola diversos povos ao longo da história social. Será estudado, também, a organização política fundada na servidão de seu povo, bem como as formas compreendidas por Espinosa para combater o estado servil. Por fim, será analisada a oposição ao Estado de servidão, em que impera a liberdade e que, na visão espinosana, será o Estado democrático.

Palavras-chave: Espinosa; La Boétie; servidão; liberdade; organização política; 
Sumário

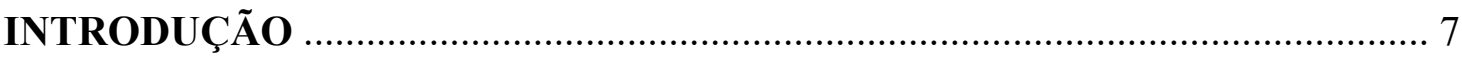

CAPÍtUlO I:

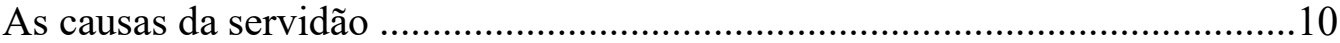

CAPÍTULO II:

A organização política servil ..........................................................................21

CAPÍTULO III:

Organização política e liberdade …………………………………………….....30

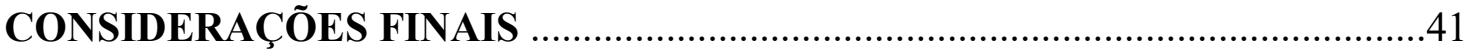

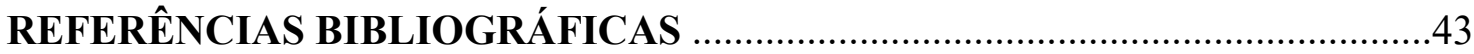




\section{Introdução}

O que explica a obediência de alguns povos diante da tirania de seus soberanos? O que explica não apenas que obedeçam ao tirano, mas que queiram obedecê-lo? Esses questionamentos foram o ponto de partida de Etiénne de La Boétie, em seu Discurso sobre a servidão voluntária, para analisar os engendramentos que fazem com que um povo não lute contra as opressões vividas pelos desmandos de governos autoritários. A dificuldade de um povo, inserido no regime da servidão, de lutar pela sua liberdade, é tema recorrente também na bibliografia de Espinosa, em especial em seus Tratado Teológico-Político e Tratado Político.

O presente trabalho tem por objetivo analisar a construção política da obediência enquanto razão de Estado. Para isso, o ponto de partida será a compreensão tanto de La Boétie, quanto de Espinosa, acerca das causas e consequências da servidão. Neste sentido, é fundamental a leitura de intérpretes da filosofia espinosana, tal qual Gilles Deleuze, Marilena Chaú, Antonio Negri, Laurent Bove, Homero Santiago e Ana Luiza Saramago Stern, assim como outros, queoferecerão elementos fundamentais para uma investigação adequada da gênese da servidão, conceito indissociável do que se entenderá por organização política servil, estado em que se experiencia a servidão do povo, na ótica de Espinosa.

O primeiro capítulo terá como objeto a análise das causas e consequências da servidão de acordo com La Boétie, bem como a formação do Estado uma vez fundado no regime servil. Será analisado, ainda que brevemente, os conceitos de liberdade, desejo, potência e paixão em Espinosa, notadamente delimitados em sua Ética. A partir de tais conceitos será possível compreender o que o autor entende acerca do tema da obediência servil. Neste sentido, a filosofia espinosana será primordial para o entendimento de como se dá a construção de regimes autoritários de governo.

O segundo capítulo, por sua vez, será voltado para o estudo da organização política pautada na servidão. Será analisada a compreensão de Espinosa acerca da composição afetiva e política desse Estado servil, assim como as consequências sociais que este tipo de política autoritária tem para seu povo e para o próprio Estado. Os intérpretes anteriormente mencionados serão de grande valia para a explicação de que forma o Estado se estrutura a partir do regime servil. Será explicado, ainda, de que 
maneira os servos voluntários, conceito trazido por La Boétie, compõem essa organização política servil, o que gera uma sociedade obediente e passiva.

O capítulo dois ainda abordará os efeitos políticos e afetivos da tirania, não apenas para o povo, mas também para seus governantes e para o próprio Estado, que fica notadamente em posição vulnerável devido à falta de liberdade de seus cidadãos. Este capítulo buscará analisar como um Estado que se funda na servidão jamais será capaz de produzir alegria para seu povo e, ainda, como estará constantemente sob a ameaça de revoltas e instabilidade política.

Por sua vez, o terceiro capítulo terá como objeto a oposição ao Estado de obediência política. A partir da filosofia de Espinosa, serão estudados os instrumentos políticos para garantia da liberdade e as consequências - positivas - que isso terá para os cidadãos e, não menos importante, para o próprio Estado. Além da estabilidade política almejada pelos governantes, o Estado em que impera a liberdade promove alegrias entre seu povo, uma vez que tem por objetivo a composição de potências individuais do povo.

Neste capítulo, será analisado, ainda, o conceito do autor de multidão multiplicidade de potências singulares - e a importância desse conceito para a formação do Estado. Para Espinosa, a multidão será guiada pela busca do bem comum de todas as singularidades que a compõe, diferentemente do Estado governado por um único soberano, cuja tendência é fugir dos ditames da razão e governar com base em interesses privados. No primeiro caso, a liberdade será regra para o povo, enquanto no segundo caso, a servidão prosperará.

A partir do estudo de Antonio Negri acerca da multidão em Espinosa, o último capítulo buscará propor, ainda, a forma de Estado que mais é capaz de compor potências, multiplicá-las, promover alegrias e trazer estabilidade política ao Estado: a democracia. Nesse sentido, será a democracia a oposição à organização política servil, por promover um estado de tolerância e liberdade, de acordo com Negri (2016). As consequências da democracia para o Estado e seus cidadãos será também objeto deste terceiro e último capítulo.

No que tange a metodologia utilizada neste trabalho, buscou-se manter a interpretação fiel da filosofia tanto de La Boétie, como de Espinosa, através da leitura de seus intérpretes e comentadores, notadamente as obras de Antonio Negri, Marilena Chauí, Ana Luiza Saramago Stern, Gilles Deleuze, Homero Santiago e Pierre Clastres. 
Tais autores foram imprescindíveis para a construção dos conceitos de Espinosa acerca dos afetos, da multidão e da democracia.

Por fim, é importante ressaltar que, embora La Boétie e Espinosa tenham sido autores dos séculos XVI e XVII, respectivamente, sua filosofia se demonstra atual e fundamental para a compreensão de que forma certas construções políticas levam ao autoritarismo do Estado e à servidão do povo, o que ocorre até os presentes dias. Os debates travados por tais autores se mostram de profunda importância para o combate à servidão enquanto pilar do Estado e, consequentemente, para a defesa da democracia como regime ideal para o exercício da liberdade. 


\section{CAPÍTULO I}

\section{As causas da servidão}

"Que vício, que triste vício é este: um número infinito de pessoas não a obedecer, mas a servir, não governadas, mas tiranizadas, sem bens, sem pais, sem vida a que possam chamar sua?" (Etiénne de La Boétie)

Étienne de La Boétie, em seu Discurso sobre a servidão voluntária, se propôs a analisar as razões que explicam o porquê de tantos povos, em momentos históricos distintos, sujeitarem-se a regimes políticos tirânicos, representados pela figura de um soberano autoritário e mais preocupado em governar para si próprio do que para seu povo, colocando, então, enquanto prioridade a satisfação de seus interesses privados em detrimento do que é melhor para seu povo.

Para compreender o fenômeno da obediência, é necessário, primeiro, entender o conceito de liberdade para La Boétie. O autor afirma que a liberdade pertence a todos, é uma característica inerente aos sujeitos, que nascem igualmente livres e detentores do direito de lutar e de reivindicar por sua liberdade. Nesse sentido, o que explicará, segundo o filósofo, a sujeição à tirania do Estado será o desejo do povo de viver sob estas condições, cujas causas, por mais diversas que sejam, produzem estados de servidão similares.

A servidão estudada por La Boétie tem o nome de servidão voluntária. Ela se explica através de três causas: o hábito; a covardia; a participaçãona tirania. Essas causas são originadas nas diferentes formas como a tirania se institui no Estado.Para o autor, a constituição da tirania influenciará a maneira não só como os sujeitos lidarão com sua vida servil, mas também a forma com que os governos se organizarão para engendrar a obediência de seu povo.

Ainda segundo o autor, o soberano pode agir de maneiras distintas com objetivo de subtrair a liberdade do súditotanto de agir, quanto de falar e até mesmo "quase de pensar" (LA BOÉTIE, 2016, p. 24);no entanto, não pode tirar-lhe a vontade de ser livre, justamente por ser algo inerente aos sujeitos.A servidão é, nesse sentido, uma ofensa à natureza dos indivíduos. Perder a liberdade, portanto, é perder a humanidade, já que "o homem é um ser-para-a-liberdade" (CLASTRES, 2011, p. 109). 
Assim, de acordo com La Boétie, entendemos que os homens nascem para viver em livre arbítrioe o que explicará, como já mencionado, a abdicação de sua condição natural para se sujeitar a uma organização de Estado pautada na vida servil será o desejo. Por ser a liberdade uma característica dos sujeitos, a servidão voluntária somente ocorrerá em estado de não deliberação de ideias, em situações nas quais o sujeito reage afetivamente a alguma causa externa.

A servidão voluntária, pois, nada mais é do que uma forma de dominação do povo pelo Estado, representado na figura de seu soberano, e a forma como o poder foi alcançado pelo tirano explicará a origem da servidão voluntária. A partir disso, o governo se sustentará, não mais pelo constante uso do medo ou da força, mas principalmente pela forma como a servidão voluntária se enraizou em seu povo.

A complexidade da questão, no entanto, está no fato de que o servo voluntário acredita estar agindo na plenitude de sua racionalidade, isto é, crê estar abrindo mão de sua liberdade sem que haja qualquer vício em sua vontade. Porém, como explica o autor, a condição servil jamais é uma escolha deliberada, fruto de processos racionais, sempre será uma violação à natureza humana e, por isso mesmo, nunca poderá decorrer de uma vontade racional. A explicação é dada por Homero Santiago:

"Somos ignorantes e desejantes. Eis um dado crucial para a complexidade de nosso ser, em sua totalidade. Fossemos só ignorantes, estaríamos próximos da vida animal, quiçá da mineral; pois com certo abuso podemos dizer que um verme bem como uma pedra igualmente ignoram; só que justo por não desejarem não produzem superstição. Fossemos só desejantes, nada ignorássemos, o verdadeiro seria para nós uma sorte de instinto; jamais se desejaria isso ou aquilo, mas só o realmente melhor, com base firme no conhecimento das causas. Nada disso. A humanidade depende inextricavelmente da amarração górdia, no ser do homem, de ignorância e desejo, certa ignorância e certa inconsciência combinadas com certo saber e certa consciência em variada proporção, mas sempre indissociáveis." (SANTIAGO, 2012, p. 15) 
Para a melhor compreensão do entendimento de La Boétie acerca do desejo por servir, é preciso utilizar a filosofia de Espinosa e seus conceitos acerca dos afetos, desejos, paixões e potência. Para este autor, afecção é a disposição de afetar e ser afetado por coisas externas. É a partir dos afetos, dessa capacidade individual de afetar coisas externas e de ser afetado por elas, que se constroem os conceitos de desejo, potência, liberdade, paixão.

$\mathrm{O}$ afeto em Espinosa não tem o teor ordinário da palavra, não se tratam de sentimentos. O conceito de afeto é axiologicamente neutro, portanto, diz respeito a uma transição, a uma passagem de uma perfeição maior a uma menor, além de seus derivados. Essas transições se dão sob certas relações com as coisas externas a si. Assim, no sentido espinosano, afeto se refere ao dinamismo do poder de afetar e de ser afetado.

É através da potência que um indivíduo demonstra sua capacidade de afecção. A potência, para o autor, é exprimida ${ }^{1}$ sempre na atualidade, não sendo, desta feita, algo a ser desenvolvido com o passar do tempo. Isto significa que um sujeito que possui certas potencialidades a possui no presente, enquanto atualidade, alguém que pode exprimir essa potência no presente, que pode afetar e ser afetado das mais diversas formas atuais.

O entendimento de Espinosa acerca dos afetos é fundamental para compreender o que leva os súditos a se submeterem ao tirano. Para o autor, o desejo não se trata de uma vontade dotada de razão, mas sim de reação afetiva à necessidade de conservar-se a vida. Sobre o tema, coloca Laurent Bove:

"Para ele [Espinosa], o desejo é a produtividade mesma da vida por meio e através dos afetos, mas isso não envolve nenhuma ideia de falta: não é um 'desejo de...', não pede complemento nominal. A natureza do desejo como afeto primário é a potência ou aptidão para fazer alguma coisa, ou seja, de produzir efeitos por si mesma. (...) O desejo é aqui uma potência de afecção, ou seja, uma capacidade de ser afetado. Isso significa ser mobilizado, modificado, transformado, tocado, etc., e

\footnotetext{
${ }^{1}$ No presente trabalho, o sentido de exprimir a natureza de algo é manifestá-la, envolvê-la e explicá-la. Para maior aprofundamento, ver: DELEUZE, Gilles. Espinosa e o problema da expressão. São Paulo: Editora 34, 2017.
} 
também a capacidade que esses efeitos têm de produzir por sua vez novos efeitos." (BOVE, 2010, p. 34)

Acerca da relação entre os conceitos espinosanos de desejo, potência, servidão e liberdade, explica Homero Santiago:

\begin{abstract}
"Servidão e liberdade são palavras de que nos servimos para indicar certa predominância na direção assumida por um desejo, portanto certa estruturação momentânea de um ser, conforme prevaleça ou o rebaixamento ou o aumento de sua potência. Entre um e outro há diferença decisiva de grau, proporção, não de natureza. Tanto servidão quanto liberdade radicam-se na mesma busca do útil, na mesma natureza desejante." (SANTIAGO, 2012, p. 16)
\end{abstract}

Para Espinosa, então, o que separa a servidão da liberdade é a variação da potência do ser. Isto é, sua capacidade de afetar e ser afetado, bem como sua capacidade de padecimento diante das coisas externas. Esta capacidade, no entanto, deriva dos encontros do ser e, consequentemente, das afecções que decorrem destes.

Segundo o autor, tanto a liberdade, quanto a servidão são inevitáveis à condição humana. No entanto, a liberdade decorre do indivíduo ser causa adequada de suas próprias paixões; seu poder, então, de afetar coisas externas, produzindo alegrias. Por outro lado, a servidão provém de certo grau de passividade do ser diante das afecções, o que acaba por provocar tristezas, limitando, assim, sua potência de agir.

Nesse sentido, compreende-se que Espinosa, assim como La Boétie, entende que ninguém, a não ser que seja dominado por causas exteriores e afetos contrários ${ }^{2}$ à sua natureza, descuida-se de desejar o que lhe é útil, ou seja, descuida-se de conservar o seu próprio ser. Por desejo, Espinosa entende que este nada mais é do que a expressão afetiva da potência do indivíduo; isto é, dos afetos decorrentes da afirmação do ser na existência, de seu intuito de conservar-se como é. Elucida o autor:

\footnotetext{
${ }^{2}$ Por afetos contrários, entende-se aqueles que levam os homens a sentidos diversos, ainda que do mesmo gênero. São aqueles afetos que não são contrários por sua natureza, mas por uma questão acidental. Para mais, ver Definição V da Parte IV, Ética de Espinosa.
} 
"Quanto mais cada um se esforça para buscar o seu útil, isto é, para conservar o seu ser, e pode [fazê-lo], tanto mais é dotado de virtude e, ao contrário, enquanto negligencia o seu útil, isto é, a conservação de seu ser, nesta medida é impotente.” (ESPINOSA, 2015, p. 409)

A afecção do desejo, no caso da servidão, será fruto de ideias inadequadas ${ }^{3}$ dos indivíduos, de que sujeitar-se à tirania é fundamental para a preservação de seu ser. Na concepção de Espinosa, ideias inadequadas são aquelas que não decorrem da ação do sujeito, que são, desta forma, marcadas por passividade e padecimento ${ }^{4}$. As ideias inadequadas são caracterizadas, portanto, pela privação, o que as difere das ideias adequadas, justamente por estas serem fruto da compreensão das causas que a geraram.

Os conceitos de desejo e liberdade estão intrinsecamente ligados. Um ser buscará em sua vida realizar encontros que o proporcionarão aumentar sua potência singular, de modo a experimentar maiores graus de liberdade. O desejo, então, perpassa essa busca pelo bem útil, pela vivência da liberdade. É possível, como já explicado, que esse desejo seja fruto de uma inadequação, de modo que essa busca acabe levando para estados de servidão, cujas causas tenta-se elucidar nesta pesquisa.

Sobre a liberdade, La Boétiea compreende enquanto absoluta, o que o difere de Espinosa. Para este autor, o livre-arbítrio é uma ilusão, pois o indivíduo precisa das coisas externas e, em razão disso, eventualmente padecerá diante dessas coisas. As causas externas são inerentes à experiência de vida do homem, que sofrerá mudanças em seu ser necessariamente por estar constantemente de frente para coisas externas a si. Nesse sentido, o homem é apenas causa parcial da mutação ${ }^{5}$. Veja-se o que diz Espinosa sobre isto:

\footnotetext{
“A bem da verdade, se não tivessem experimentado que fazemos muitas coisas das quais nos arrependemos, e que frequentemente, ao nos depararmos com afetos contrários, vemos o melhor e seguimos o pior, nada os impediria de crer que tudo fazemos livremente. [...] Pois cada um modera tudo por seu afeto, e aqueles que
}

\footnotetext{
${ }^{3}$ Ver Proposição I, Parte III, op cit.

${ }^{4}$ Ver Proposição III, Parte III, op cit.

${ }^{5}$ Ver Demonstração da Proposição I, Parte III, op cit.
} 
se defrontam com afetos contrários não sabem o que querem [...]." (ESPINOSA, 2015, p. 246-247).

Espinosa entenderá, assim, a servidão como sendo a "impotência humana para moderar e coibir afetos" (ESPINOSA, 2015, p. 372). As paixões ou afetos, para o filósofo, se preservam na existência na medida da sua causa externa, em razão disso, podem superar a potência do próprio ser, que é limitada ${ }^{6}$. Para o autor, o conhecimento daquilo que é verdadeiro, ou seja, ter ideias adequadas, por si só, não tem força para coibir os afetos. Apenas enquanto considerado como afeto, o conhecimento será capaz de refrear paixões.

Disto pode-se inferir que o servo, ainda que conheça sua condição servil, não será capaz de coibir seu desejo pela servidão, na medida em que as causas externas políticas de Estado para enraizar a servidão humana - superam a potência do indivíduo, e seu conhecimento, que não é afeto, não possui força para coibir essa ideia inadequada, que leva ao padecimento, refreia a potência do ser, e, consequentemente, provoca a experimentação de tristezas.

No caso da servidão voluntária de La Boétie, a causa externa que explicará o desejo por servir tem origem nas três espécies de tirania - quais sejam, aquela conquistadapor meio da guerra; passada através da hereditariedade;nos casos em que o Estado foi concedido ao tirano pelo povo. Essas espécies de tirania explicarão a servidão voluntária a partir de três circunstâncias: o hábito, a covardia e a participação na tiraria.

Para o filósofo, as três distintas formas de ascensão do tirano ao poder terão implicações na maneira como povo se sujeitará a este poder e abdicará de sua própria liberdade. Por isto, será preciso analisar cada forma de alcance do poder pelo tirano para entender de que forma a servidão voluntária se tornou um desejo daquela sociedade. Como coloca o autor:

"Uma coisa é certa, porém: os homens, enquanto neles houver algo de humano, só se deixam subjugar se foram forçados ou enganados;" (LA BOÉTIE, 2016, p. 12)

\footnotetext{
${ }^{6}$ Ver Proposições III e VI da Parte IV da Ética de Espinosa.
} 
Os tiranos que chegam ao poder pela guerra, que conquistam um povo antes conhecedor da liberdade, portam-se "como quem pisa em terras conquistadas" (LA BOÉTIE, 2016, p. 11). O tônus da violência acovarda o povo sobrevivente da guerra, que abdica de sua liberdade para continuar vivo. Tornam-se, assim, servos do novo tirano, perdem a valentia de lutar pela liberdade.

A tirania que decorre da guerra tem como consequência a servidão voluntária originada na covardia. Se, em um primeiro momento, a servidão decorre diretamente da força do soberano, passada a demonstração de violência, o medo e a covardia se instalam de tal forma no povo, que a liberdade deixa de ser uma escolha e a sujeição passa a ser um desejo. Afirma o filósofo:

\begin{abstract}
"Incrível coisa é ver o povo, uma vez subjugado, cair em tão profundo esquecimento da liberdade que não desperta nem a recupera; antes começa a servir com tanta prontidão e boa vontade que parece ter perdido não a liberdade, mas a servidão.” (LA BOÉTIE, 2016, p. 12)
\end{abstract}

Uma vez estabelecido no poder pela guerra, o tirano atua politicamente para que seus sucessores sejam aqueles de seu próprio sangue; buscam, assim, a transmissão do poder através da hereditariedade. Esta espécie de tirania, a hereditária, faz com que o fenômeno da servidão voluntária seja causado pelo hábito - mais uma das três hipóteses de origem da servidão voluntária. Mais uma vez, coloca o autor:

\footnotetext{
"Assim é: os homens nascem sob o jugo, são criados na servidão, sem olharem para lá dela, limitam-se a viver tal qual como nasceram, nunca pensam ter outro direito nem outro bem senão o que encontraram ao nascer, aceitam como natural o estado que acharam à nascença.” (LA BOÉTIE, 2016, p. 12)
}

Estes casos são de povos nascidos no seio da tirania, que jamais gozaram da liberdade, e que, por não a conhecerem, não lutarão contra sua condição servil. São servos voluntários condicionados pelo hábito, pessoas cuja origem é a tirania, 
habituadas à servidão, incapazes, inclusive, de se enxergarem na sua própria condição de servos. Veja-se o que diz La Boétie:

"Mas o costume, que sobre nós exerce um poder considerável, tem uma grande força de nos ensinar a servir e [...] a engolir tudo, até que deixamos de sentir o amargor do veneno da servidão." (LA BOÉTIE, 2016, p. 12)

É como pedir para um pássaro que jamais voou, que voe. Ele não saberá que voar lhe é inerente, e, por isso mesmo, poderá passar uma vida inteira sem fazê-lo, simplesmente por desconhecer sua própria condição. O mesmo acontece com alguém que jamais experimentou a liberdade. Como poderá saber o que é ser livre, alguém que nasceu no seio da tirania? Poucas são as pessoas cuja alma é capaz de não se acostumar à sujeição (LA BOÉTIE, 2016, p. 16), mesmo só tendo experimentado isto em sua vida. Veja-se:

"É natural no homem o ser livre e o querer sê-lo; mas está igualmente na sua natureza ficar com certos hábitos que a educação lhe dá.” (LA BOÉTIE, 2016, p. 16)

A terceira espécie de ascensão ao poder ocorre por meio da entrega do Estado pelo povo ao tirano. Nesses casos, para que se sustente no governo, o tirano precisa que o povo se sinta parte da estrutura de poder. Neste contexto, se dá a terceira e última causa para a servidão voluntária: a participação na tirania.

Nessa hipótese, o servo abre mão de sua liberdade pela participação no governo. Esta participação não significa, em nenhuma medida, deliberar sobre as decisões a serem tomadas, uma vez que apenas as vontades do soberano serão atendidas - e não há dúvidas quanto a isso - mas ser o súdito beneficiado pelo regime da tirania, receber favores e mimos, estar próximo ao tirano, viver às custas da servidão alheia. Define o autor:

"E, pelos favores, ganhos e lucros que os tiranos concedem chega-se a isto: são quase tantas pessoas a 
quem a tirania parece proveitosa como as que prezam a liberdade.” (LA BOÉTIE, 2016, p. 24)

Os que vivem em torno do tirano, que "mendigam seus favores" (LA BOÉTIE, 20016, p. 26), estão constantemente vivendo uma vida que não lhes pertence. Executam as ordens de seu rei para oprimir o povo ao qual pertencem, renunciam à liberdade em troca de muito pouco e, muitas vezes, abdicam de sua própria individualidade para orbitar seu soberano. Veja-se:

\footnotetext{
"Ponham eles algum freio à ambição, renunciem um pouco à avareza, olhem depois para si próprios, vejamse bem e perceberão claramente que os camponeses, os servos que eles espezinham e tratam como escravos são em comparação com eles, livres e felizes." (LA BOÉTIE, 2016, p. 25).
}

Assim, podemos explicar as três causas da servidão voluntária - hábito, covardia e participação na tirania - como sendo o desejo do súdito de perseverar seu ser, ainda que isto signifique abdicar da própria liberdade para viver uma vida sujeita às arbitrariedadesde um tirano. Desejo este, frisa-se, não resultante de um processo racional do indivíduo, mas sim afetivo no sentido de produzir efeitos e mutações no ser.

É importante a compreensão de que tanto súditos, quanto tirano, são servos nessa relação que diminui a potência de seus seres. O povo, servo por abrir mão de sua liberdade, de sua potência, de poder ser quem se é; o tirano por estar em uma relação que também diminui a potência de seu ser e impede que a organização de seu Estado produza qualquer coisa que não seja tristeza aos seus súditos e a si mesmo.

O princípio da política, na concepção espinosana, nada mais é que a habilidade contínua de composição de potências (ESPINOSA, 2003), buscando, é claro, que o povo experiencie situações que ampliem as suas potências de agir. Nesse sentido, entende-se que o corpo humano pode ser afetado de diversas maneiras. Aquilo que amplia a potência de agir do corpo é entendido por Espinosa como sendo paixões alegres, contrárias as paixões tristes, que diminuem a potência do ser. Segundo o autor: 


\begin{abstract}
"Digo que agimos quando ocorre em nós ou fora de nós algo de que somos causa adequada, isto é, quando de nossa natureza segue em nós ou fora de nós algo que pode ser estendido clara e distintamente só por ela mesma. Digo, ao contrário, que padecemos quando em nós ocorre algo, ou de nossas naturezas segue algo, de que não somos causa senão parcial.” (ESPINOSA, 2015, p. 237)
\end{abstract}

A partir disso, entende-se que é absolutamente impossível não ser necessário nada exterior a si para conservar o próprio ser. O papel do Estado, então, é buscar aquilo que é de utilidade comum para todos (ESPINOSA, 2003). Isto é, cabe ao Estado compor as potências de modo que suas políticas propiciem a experimentação de alegrias pelos súditos, coibindo, consequentemente, que tristezas sejam vividas pelo povo.

Um Estado que se funda na servidão está, por consequência, fugindo desse princípio, pois é incapaz de compor relações afetivas que ampliem a potência de agir do povo. Um governo cujo âmago é a tristeza jamais será capaz de produzir nada além de tristezas, e verá seu povo fadado a viver na flutuação do ânimo, que alimenta a discórdia do povo (ESPINOSA, 2003).

Para o filósofo, a experiência humana será necessariamente uma experiência política, que é movida não pela razão, mas sim pelo desejo de seus participantes, justamente por ser o desejo algo inerente à natureza humana. Sobre o assunto, coloca Marilena Chauí:

“(...) é excluída a suposição tradicional (Greco-romana e escolástica) de que a política tem como causa e fundamento a presença de uma alma racional no homem e, consequentemente, fica invalidada a tentativa para compreender a experiência e as formas políticas em sua constituição, conservação e destruição como obra da razão

ou de seus desatinos - "não é dos ensinamentos da razão" que a experiência política deve ser deduzida." (CHAUI, 2003, p. 224) 
Em termos políticos e afetivos, portanto, o papel do Estado de controlar a variação dos afetos para assegurar uma maior liberdade ao povo, menor imprevisibilidade política e, consequentemente, menor grau de servidão. O Estado que falha em controlar a flutuação de ânimo, que é incapaz de compor potências, promovendo, consequentemente, alegrias, é aquele em que impera a organização política servil, que se buscará analisar com maior profundidade no próximo capítulo. 


\title{
CAPÍTULO II
}

\section{A organização política servil}

\begin{abstract}
"Assim são os tiranos: quanto mais eles roubam, saqueiam, exigem, quanto mais arruínam e destroem, quanto mais se lhes der e mais serviços se lhe prestarem, mais eles se fortalecem e se robustecem até aniquilarem e destruirem tudo. Se nada lhes der, se não se the obedecer, eles, sem ser preciso luta ou combate, acabarão por ficar nus, pobres e sem nada; [...]" (Etiénne de La Boétie)
\end{abstract}

Como visto no capítulo anterior, Espinosa entende a servidão enquantoa impotência dos homens de coibir e refrear afetos. Isto porque aquele que é governado por seus afetos está condenado a não ser senhor de si e, como afirma o autor, será capaz de enxergar o que é melhor para si, aquilo que lhe é útil, mas ainda assim escolherá seguir o pior caminho (ESPINOSA, 2015).

O contrário à servidão é a liberdade que, para La Boétie, é um direito natural dos indivíduos. Espinosa, por sua vez, entende o direito natural sob outra perspectiva. Para o filósofo, o direito natural é determinado pela potência de cada um. Tanto mais potência tem um Estado, tanto mais potência tem seu povo. Não se trata, portanto, para este autor, de algo previamente dado, mas sim da capacidade de agir, de ser causa adequada de suas próprias ações. Assim, a liberdade, vista como direito natural para La Boétie, é, para Espinosa, decorrente da potência de cada um, de sua capacidade de ser causa adequada, de não padecer.

É papel do Estado formar uma sociedade que busca compor direitos, formando o que Espinosa chama de direito comum (ESPINOSA, 2009). A busca pelo direito comum, pelo bem comum, norteará o governo, que não agirá pautado em afetos; ao contrário, será guiado pela razão, por aquilo que será útil ao povo e ao próprio governo. Esse Estado será mais capaz de produzir liberdade, justamente porque coibirá ações pautadas nos afetos e, consequentemente, aumentará a potência individual de agir a partir da garantia do bem comum para todos, daquilo que é útil para todo o povo. 
O direito comum, pois, é definido a partir da potência da multidão. Tanto mais direito comum existe, tanto mais aumenta-se a potência do povo.Nos termos do próprio filósofo:

\footnotetext{
"Onde os homens têm direitos comuns e todos são conduzidos (como que por uma só mente) é certo que cada um deles tem tanto menos direito quanto os restantes juntos são mais potentes que eles, ou seja, não tem realmente sobre a natureza nenhum direito para além daquele que o direito comum lhe concede." (ESPINOSA, 2009, p. 20-21).
}

Assegurar que os direitos e as leis sejam ditados pela razão é fundamental ao soberano, que deve agir de modo a coibir atitudes movidas por afetos, promovendo, assim, a formação de bons encontros e, consequentemente, o aumento de potências individuas dos súditos.

Este é o cerne de uma sociedade livre, que diferentemente de sociedades servis, não vive sob o jugo de um tirano primordialmente agindo de acordo com os ditames dos afetos. Em Estados em que a servidão impera, o tirano não busca com seu governo proporcionar direitos comuns, não busca aquilo que é útil aos seus súditos, visa, sempre, satisfazer interesses pessoais; por isso, a potência de todo o povo, e do próprio governo, é refreada.

Disto decorre que Estados constituídos sob o medo, fundados na servidão humana, estão mais vulneráveis à destruição, porque o medo provoca a indignação do povo, o que eventualmente gerará comoção popular contra o soberano. Um Estado não pode, por óbvio, dar aso a sua própria destruição; não pode, portanto, ser governado de maneira distinta da racionalidade. Os direitos de um Estado serão os mesmos da potência do que Espinosa entende por multidão e, por isso, buscar o que for mais útil aos súditos, será também de grande utilidade para o próprio Estado, conquistando, dessa forma, estabilidade política.

O autor entende a multidão a partir da composição da multiplicidade de potências individuais, sempre exprimida em sua atualidade (NEGRI, 2016).Compreende-se que a multidão concede a alguém - o soberano - "o direito e, consequentemente, o poder" (ESPINOSA, 2009, p. 25) de governar, mas este não 
deverá fazê-lo pensando em seu próprio bem; deve considerar como bom apenas aquilo que será bom para seus súditos, sendo conduzido pela razão. É da natureza dos indivíduos buscar a paz, no entanto, esta jamais pode ser obtida quando as ações do soberano não são guiadas visando ao respeito dos direitos comuns dos cidadãos. Veja-se o que diz Espinosa sobre o tema:

“Com efeito, há de se ter em conta, em primeiro lugar, que assim como no estado natural o homem mais potente e que mais está sob jurisdição de si próprio é aquele que se conduz pela razão, assim também a cidade mais potente e mais sob jurisdição de si própria será aquela que é fundada e dirigida pela razão. Com efeito, o direito da cidade determina-se pela potência da multidão como que por uma só mente."7

A importância política de se governar seguindo a razão reside no fato de que o súdito que vêseus direitos comuns sendo respeitados obedecerá às ordens de seu soberano (ESPINOSA, 2009, p. 28). Esse Estado, que privilegia a razão em detrimento de decisões afetivas, ao qual Espinosa dá o nome de Estado civil, tem como principal feito diminuir a sensação de medo entre seu povo, de buscar agir em prol do direito comum.

Assim, no Estado civil, os cidadãos são mais livres, pois ao agirem estarão impulsionados a fazê-lo segundo a razão, por viverem em um Estado que ensina a buscar o útil a cada um dos indivíduos. Disso se segue que pertence menos ao Estado exercer direitos que provoquem a revolta da maioria. Na perspectiva de Espinosa:

"[...] é certo que a potência e o direito da cidade diminuem na medida em que ela própria ofereça motivos para que vários conspirem. Há certamente coisas de que a cidade deve ter medo, e da mesma forma que cada cidadão ou cada homem no estado natural, assim, também a cidade está tanto menos sob jurisdição própria quanto maior é o motivo que se tem para temer. Isto

\footnotetext{
${ }^{7}$ ESPINOSA, Baruch de. Tratado Político, III, 7, in NEGRI, Antonio. Espinosa subversivo e outros escritos. Belo Horizonte: Autêntica, 2016, p. 62-63.
} 
quanto ao direito dos poderes soberanos sobre os súditos." (ESPINOSA, 2009, p. 30-31)

A liberdade, por esta lógica, é fundamental para a continuidade do Estado. Cidadãos livres não conspiram contra o soberano; ao contrário, aprendem com o próprio Estado a agir sob os ditames da razão, buscando para si aquilo que lhes for mais útil, que lhes aumente a potência.

Um Estado que peca, que faz ou deixa de fazer coisas que dão causa à sua própria ruína, age contra a razão, e, consequentemente, "está em falta para consigo" (ESPINOSA, 2009, p. 39). Este é um Estado em que há o império do medo, que é ditado pelos afetos, que dá causa para sua própria destruição, no qual os cidadãos são meros servos do soberano, estão ali para o servir, sem que haja qualquer preocupação do governo de buscar os direitos comuns.

Existe, assim, uma relação bilateral entre cidadãos e Estado. Seus direitos - de súditos e soberanos - estão intrinsecamente ligados. O soberano, em nenhuma medida, tem mais direitos que seu povo, e deve, tanto mais seja possível, cumprir com as leis, que devem visar ao direito comumpara afastar a indignação da multidão.

Nesse contexto, o servo age em benefício alheio, esforça-se para ser útil para um terceiro, enquanto o homem livre buscará atuar se guiando por aquilo que é de utilidade comum, de modo que, ao mesmo tempo em que age por si, acaba agindo em benefício do próprio Estado, por pensar na coletividade, e não apenas em satisfazer seus desejos.Veja-se:

"O agir de acordo com uma ordem, quer dizer, a obediência, retira, é um fato, até certo ponto a liberdade; não torna, porém, automaticamente um homem escravo, já que só o móbil da ação pode levar a tanto. Se o fim da ação não é a utilidade de quem a pratica, mas daquele que a ordena, então o que a pratica é escravo e inútil a si próprio; porém, num regime político e num Estado em que a lei suprema é o bem-estar de todo o povo e não daquele que manda, quem obedece em tudo à autoridade não deve considerar-se escravo e inútil a si mesmo, mas apenas súdito.” (ESPINOSA, 2014, p. 241) 
Espinosa entende que a tirania ocorre precisamente quando um Estado e seu povo se voltam a agir politicamente para fins particulares do tirano, fazendo com que as leis e o direito tenham como foco o benefício individual do soberano. O povo que vive sob esta dinâmica está fadado à servidão, e estará agindo conforme o que pensador define como obediência servil (STERN, 2013, p. 238).

O contraponto a um Estado em que impera a obediência servil é, por certo, um Estado democrático - o qual será analisado em momento oportuno no próximo capítulo. Nesses Estados, as leis privilegiam a busca do bem comum, é de interesse do cidadão obedecer às leis, uma vez que elas serão construídas visando a composição de potências, gerando alegrias. De acordo com Stern:

\begin{abstract}
"Obedecer de forma servil é realizar o bom que nos é imposto por outrem, seguir uma ordem de valores exterior ao próprio conatus individual. Neste sentido, o que caracteriza a obediência servil é tomar como primeira e superior uma ordem estatal ou do soberano, em detrimento do próprio juízo de utilidade e valor individual. [...] A obediência servil reduz o indivíduo à passividade pois inscreve suas ações na servidão de ser movido por ordens heterônomas." (STERN, 2013, p. 239)
\end{abstract}

Aquele que age sob os ditames da razão, diz Espinosa, jamais estará obedecendo (ESPINOSA, 2009), isto porque quem age racionalmente estará sendo causa adequada de seus atos, enquanto que o ser movido pelos afetos estará sempre, necessariamente, padecendo e sendo causa apenas parcial de suas atitudes.

É importante esclarecer que, nesse ponto, trata-se da liberdade ética, que permeia o indivíduo, porquanto a liberdade política diz respeito ao exercício do poder político por parte do Estado em prol do direito comum de seu povo. Um Estado fundado na servidão afasta seus súditos da possibilidade de exercer a liberdade ética, por criar instrumentos políticos que coíbem ações que visam o direito comum e, por conseguinte, que diminuem a potência individual de agir.

A distinção entre a liberdade ética e a política é fundamental para compreender a obediência servil. Um cidadão que obedece às leis de um Estado cujo norte é a construção do bem comum, não estará perdendo sua liberdade, porque estará, em muitas 
medidas, agindo em prol do que é útil tanto coletivamente, quanto para si próprio. $\mathrm{O}$ contrário disto é o povo movido pelo medo. Nestes casos há que se falar em obediência servil, uma vez que o cidadão agirá movido por afetos - sendo o principal deles o medo - e o direito que prevalecerá será, por esta lógica, não o comum, mas sim o do soberano. Noutras palavras:

\begin{abstract}
"Uma multidão livre é mais levada pela esperança que pelo medo, tem sua potência aumentada por paixões alegres que perpassam o campo social. Já os escravos são dominados pelo medo, a servidão política é caracterizada pelo império das paixões que propiciam a passividade, uma multidão alienada de seus instrumentos de resistência, mais próxima da impotência.” (STERN, 2013, p. 243)
\end{abstract}

Um Estado de organização servil é constituído pelo desejo de servir, cujas causas já foram elucidadas no capítulo anterior, de acordo com a filosofia de La Boétie. O desejo de servir sustenta a tirania (STERN, 2013, p. 245). Desta feita. a condição de servidão não é determinada por características pessoais do povo, em verdade, a forma como se constitui o Estado é primordial para definir a servidão do povo.

A noção de obediência precisa ser pensada sob a ótica da vontade constante de cumprir com aquilo que as leis e o Direito entendem por bom, ainda que aquilo não seja útil para o cidadão. O desejo de obedecer, nesses casos, existe pela crença de que cumprir com aquilo que está na lei proporcionará algo de bom ou útil se realizado. A servidão, por esta lógica, ocorrerá quando as leis não refletem o direito comum, quando são tomadas pelos interesses privados daqueles que estão no poder. Veja-se:

\footnotetext{
"Quando o direito não exprime o bem comum mas é privatizado em interesses particulares, quando o medo encastela o poder em discursos da transcendência a obediência é experiência de servidão." (STERN, 2013, p.
} 253)

Um povo servil, como visto, acredita que sua obediência gerará algo útil, um bem comum. As origens do desejo de servir - ou, como chama La Boétie, da servidão 
voluntária -, terão como ponto comum a crença de que a obediência pode dar causa a um bem maior. Isto se explica de duas formas: medo e esperança. O medo de provocar um mal maior que a própria servidão é um dos fatores que motivam a obediência. $\mathrm{O}$ mesmo é válido para a esperança de um bem maior, isto é, a ideia de que a servidão poderá ter recompensas futuras.

Para o Estado, não é importante saber as razões pelas quais o povo o obedece, o que de fato importa é sua obediência. Entretanto, a obediência fundada em ações que visam o direito comum do povo é mais "poderosa" (STERN, 2013, p. 361) do que aquela constituída pelo medo. Isto porque as ações pautadas no medo geram revoltas, indignações que eventualmente podem causar o fim do Estado. Coloca Ana Luiza Saramago:

"É ao governar os ânimos, de modo que os súditos convençam-se da utilidade da obediência, que o poder se exerce da forma mais poderosa. Poder que opera a inversão paradoxal do útil individual e coletivo em utilidade alheia, que leva os indivíduos e a multidão a buscarem o bem do Estado ou do soberano mesmo quando este tende a aniquilar o conatus individual e/ou coletivo." (STERN, 2013, p. 261)

O medo, então, não é o melhor alicerce para assegurar a obediência de um povo. O soberano que é respeitado e amado por seus súditos será mais próspero em seu governo, por seu poder estar menos propenso a ser questionado pelo povo. O filósofo, entretanto, entende que é preferível ao soberano ser amado por aqueles a quem governa, pois, assim, a obediência civil será fundada não apenas no desejo de servir, como também na certeza de se estar agindo em busca de algo útil, comum a todos. Neste sentido:

"O soberano deve ser visto por seus súditos com qualidades especiais, uma pessoa digna de admiração. Estamos aqui diante, portanto, de uma forma específica de amor que pode estreitar os laços de obediência e alimentar a servidão nas mentes da multidão: a adoração, o amor por aquele a quem se tem admiração. O soberano 
adorado encontra mais facilmente o consentimento da multidão que lhe venera, e a obediência mais poderosa pois permeada por alegrias passivas." (STERN, 2013, p. 267)

Ao agir politicamente, o soberano tem o poder de provocar afetos, paixões alegres ou tristes, de construir um ambiente sócio-político que aumente as potências individuais de seus súditos, ou ainda que as refreie. O poder, quando fundado no medo, não será capaz de propiciar alegrias, porque, sob os desmandos do Estado, os súditos não serão causa adequada de suas próprias ações, agirão por medo, afeto que refreia a potência de agir.

O contraponto a um Estado tirânico, fundado na obediência servil, é a democracia. Em Estados democráticos a liberdade é a regra, ainda que esta não seja absoluta, como afirma Espinosa, porque, como já mencionado, em alguma medida os homens padecerão por paixões tristes. Haverá, nesses casos, o desejo de servir, assim como há em uma tirania, porém, este desejo estará edificado na ideia de que a obediência é necessária para o cumprimento de leis alinhadas com o bem comum do povo. Na visão do filósofo:

"O agir de acordo com uma ordem, quer dizer, a obediência, retira, é um fato, até certo ponto a liberdade; não torna, porém, automaticamente um homem escravo, já que só o móbil da ação pode levar a tanto. Se o fim da ação não é a utilidade de quem a pratica, mas daquele que a ordena, então o que a pratica é escravo e inútil a si próprio; porém, num regime político e num Estado em que a lei suprema é o bem-estar de todo o povo e não daquele que manda, quem obedece em tudo à autoridade não deve considerar-se escravo e inútil a si mesmo, mas apenas súdito.” (ESPINOSA, 2003, p. 241)

Nesse sentido, os Estados democráticos são mais fortes, mais estáveis, pela capacidade de seu soberano governar orientado pela razão, por não se instituir no medo ou mesmo na esperança do povo de que a servidão traga posteriormente um bem maior ou um mal menor. São Estados que não estão propícios a serem destruídos pelo próprio 
povo, porque não dão causa à própria ruína ao agirem contra aquilo que lhes é útil a si mesmos ou aos seus cidadãos. Sobre isto trata, de forma aprofundada, o próximo capítulo. 


\title{
CAPÍTULO III:
}

\section{Organização política e liberdade}

\author{
"A democracia é a mais alta forma na qual a sociedade \\ se exprime, porque ela é a forma mais ampla na qual a \\ sociedade natural se exprime, como sociedade \\ politica."(Antonio Negri)
}

O esforço de tornar-se livre, na visão espinosana, perpassa o caminho de busca por ampliar a potência de agir. Disto decorre que, a liberdade é uma experiência de alegria. Ora, se a potência humana se amplia, isto é, quanto maior a capacidade do homem de ampliar seu poder de afecção, mais este será causa adequada de seus afetos; logo, experimentará mais alegrias. Assim, a liberdade nada mais pode ser do que uma experiência de viver afetos alegres, o que só poderá ocorrer com o aumento da potência de agir.

Espinosa não compreende a liberdade enquanto um livre-arbítrio. Para o autor, a liberdade não nasce com os homens, sua condição mais comum é a servidão, por estar sujeito a ver sua potência de agir diminuída em função de causas externas. Neste sentido, o autor entende a liberdade como sendo um esforço; o esforço de torna-se, cada vez mais,causa adequada de suas paixões. A condição livre do homem é, portanto, fruto de uma experiência da razão (STERN, 2009). Veja-se:

\footnotetext{
"Enquanto a liberdade caracteriza-se pela atividade, pela experiência de alegrias ativas e pelo encadeamento racional de ideias adequadas na mente, a servidão é o universo da passividade, dos encontros aleatórios, das paixões e da imaginação.” (STERN, 2009, p.58-59)
}

Os homens sempre e necessariamente estarão diante de encontros capazes de alterar a potência de agir de seu ser, tanto no sentido de ampliá-la, quanto no sentido de diminuí-la. Um indivíduo só existe enquanto inserido na coletividade, afetando e sendo afetado. O ser humano não existe por si só. São as trocas e encontros entre os homens que o fazem ser o que é. 
Nesse sentido, a liberdade é uma experiência contínua. Alcançá-la não significa que seu estado será permanente, pois os homens estarão frequentemente diante de causas externas que os levam ao padecimento. Para ser livre, é preciso, portanto, um esforço contínuo de afirmação da potência de agir. A própria existência do homem é uma luta contínua contra o padecimento.

Segundo coloca Antonio Negri, a potência é "tão mais forte quanto maior é o número dos homens que imaginamos empenhados nesse processo de conhecimento" (NEGRI, 2016, p. 67). Daí, pode-se concluir que a experiência de liberdade é uma experiência conjunta, dado que não se pode experimentar maiores graus de liberdade em uma sociedade fadada à servidão. É por esta razão que Espinosa entende a liberdade em relação ao processo político.

O filósofo entende, portanto, que a existência do ser humano pressupõe a relação com outros seres humanos, a formação de uma sociedade. Os sujeitos, assevera Espinosa, não podem existir se não em uma sociedade, vivendo encontros, experimentando afecções, agindo, padecendo. O processo de subjetivação dos homens decorre, necessariamente, das relações compostas entre estes, das trocas sociais. Somente nesta circunstância o homem criará consciência de si mesmo, de "sua própria existência" (STERN, 2009, p.66).

Este ser social é compreendido, ainda, pelo filósofo, a partir de uma lógica coletiva, de "multiplicidade de singularidades" (STERN, 2009, p. 67), pelo conceito de multidão, entendido enquanto "potência física" (NEGRI, 2016, p. 68). Em seu sentido espinosano, multidão não se confunde com povo, nem mesmo com massa. Multidão é composta por um sujeito coletivo, que pode agir de maneira unificada, mas que, ao mesmo tempo, conserva as singularidades dos sujeitos que a compõe. Homero Santiago, em seu artigo "O que é, quem é a multidão" analisa tal conceito:

"Pelo conceito de multidão, busca-se conceber o sujeito coletivo em sua inteira positividade e amplitude; no limite, ele se refere a todos, todos que são explorados, que lutam pela construção de um mundo comum e que se são, como multidão, responsáveis pela riqueza social, exatamente porque portadores do trabalho vivo, ou seja, de uma "pobreza" (um termo que Negri usa num sentido muito preciso de que se serve Marx) que "não é 
simplesmente miséria, mas é possibilidade de muitíssimas coisas, que o desejo indica e o trabalho produz". Em suma, multidão é o nome do sujeito que tudo produz: a riqueza, a realidade, o mundo social. E por isso revela-se também um conceito ontológico." (SANTIAGO, 2018, p. 2)

Antonio Negri desenvolveu seu conceito de multidão a partir da filosofia espinosana, compreendendo esta como conceito de classe ${ }^{8}$. Este autor entende, ainda, que a multidão desafia as representações, por ser uma "multiplicidade imensurável" (NEGRI, 2004, p. 17). Ainda segundo Negri, "o povo constitui um corpo social; a multidão não, porque a multidão é a carne da vida" (NEGRI, 2004, p. 17), por isso, tais conceitos - de povo e multidão - não se assemelham e não podem ser confundidos. Sobre isso, assevera Ana Luiza Saramago Stern:

"O sujeito coletivo multidão constitui-se independente de
qualquer organização estatal. Embora possa vir a
organizar-se em Estado, a multidão constitui-se do
esforço singular de cada um de seus constituintes [...]" (STERN, 2009, p. 88-89)

A multidão é organizada, afirma Negri; constitui-se a partir da auto-organização dos sujeitos que a compõem, não é dada por algo maior - o Estado, é imanente ${ }^{9}$. Multidão, portanto, é potência, elemento constitutivo do ser. Assim como o homem, a multidão luta para perseverar em seu ser. As potências singulares que a compõem dão o limite de sua liberdade. No mesmo sentido, quanto mais guiados pela razão, mais a multidão estará voltada para a busca do bem comum e de uma convivência social pacífica.

Nesse contexto, a relação do poder político com a multidão é de imanência. $\mathrm{Na}$ filosofia espinosana não há que se falar em poder político transcendente; isto é, na ideia de que os sujeitos abrem mão de seus direitos em nome da construção da soberania do

\footnotetext{
${ }^{8} \mathrm{O}$ conceito de classe da multidão não se confunde com a noção de classe trabalhadora, que é limitada, uma vez que esta compreende apenas trabalhadores pertencentes a lógica da produção social (NEGRI, 2004, p. 16).

${ }^{9}$ Imanência é um conceito filosófico que entende algo como aquilo que tem em si próprio princípio e fim, não é imposto por algo superior. Para maior aprofundamento, ver: CHAUÍ, Marilena. Anervura do real II. Imanência e liberdade em Espinosa. São Paulo: Companhia das Letras, 2016.
} 
Estado, governado por um único representante do povo. Assim, quanto mais potência tem a multidão, mais potência terá o Estado.

O Estado autônomo deverá ser guiado pelos ditames da razão. Assim como a liberdade, Espinosa afirma que a razão é uma experiência que deve ser constantemente buscada. Quando movidos pela razão, os homens poderão identificar aquilo que lhes é útil, que lhes dá condições para viver pacificamente em sociedade. Ao contrário, quando norteados por ideias inadequadas, padecerão e, consequentemente, não viverão de forma pacífica com seus semelhantes. Dessa forma, quanto mais o Estado age com base na razão, mais a multidão também agirá dessa forma.

Disto decorre que a multidão se constituirá a partir da identificação afetiva de semelhantes em busca de aumentar a potência individual do ser, por conseguinte, buscando o bem comum, o que, volta-se a afirmar, somente será encontrado mediante o uso da razão nas ações tanto dos indivíduos, quanto do Estado.Sobre o assunto, afirma o filósofo:

"Nada é mais útil ao homem do que o próprio homem. Quero com isso dizer que os homens não podem aspirar a nada que seja mais vantajoso para conservar o seu ser do que estarem, todos, em concordância em tudo, de maneira que as mentes e os corpos de todos componham como que uma só mente e um só corpo, e que todos, em conjunto, se esforcem, tanto quanto possam, por conservar o seu ser, e que busquem, juntos, o que é de utilidade comum para todos. Disso se segue que os homens que se regem pela razão, isto é, os homens que buscam, sob a condução da razão, o que lhes é útil, nada apetecem para si que não desejem também para os outros e são, por isso, juntos, confiáveis e leais."

Segundo Negri, a partir da filosofia de Espinosa, é possível compreender que a multidão, guiada pelos ditames da razão, formará a chamada sociedade civil. Essa sociedade se funda na dinâmica afetiva, enquanto sociedades servis decorrem da má organização dos afetos e potências, o que gera, por óbvio, políticas - ou não políticas -

\footnotetext{
${ }^{10}$ Ética, Parte IV, Escólio da Proposição 18. In: NEGRI, Antonio. Espinosa Subversivo e outros escritos. Belo Horizonte: Autêntica, 2016, p. 75.
} 
que agravam desigualdades e conflitos, promovendo o medo e outras tristezas. Nos casos das organizações políticas servis, as instituições falham na busca de composição das potências singulares. Assim, falha também a busca pelo bem comum e a construção de uma dinâmica afetiva visando o útil comum. Isto ocorre porque as sociedades servis não tem como norte a racionalidade, agem principalmente de acordo comas paixões tristes, trazendo instabilidade política e afetiva para aqueles que a compõem.

Então, o estado servil é aquele em que os sujeitos estão governados pelas paixões tristes, que podem ser contrárias aos demais semelhantes. A diferença, desta forma, entre o estado civil e aquele em que impera a servidão está, justamente, nos afetos provocados pelas relações compostas entre os seres. Nesta lógica, a servidão impera quando há impossibilidade de construção do comum, pela ausência ou impossibilidade de composição das potências entre os homens.

Disto é possível inferir que o que caracteriza as sociedades livres é a construção do comum, de leis e instituições políticas cujo objetivo é a composição das relações entre os sujeitos que a elas pertencem, resultando, assim, na ampliação da potência de agir dos indivíduos. Acrescenta Ana Luiza Saramago Stern:

\footnotetext{
"Quando, no entanto, uma organização social se mantém, não pela constituição do comum, mas pela imposição de interesses de um ou mais particulares; quando não são relações de composição, mas o medo recíproco e a opressão são os afetos dominantes numa multidão; ainda que sob a aparência de institucionalização do poder e das leis, não podemos caracterizar tal sociedade como um estado civil; [...]" (STERN, 2009, p. 98-99)
}

Em uma sociedade civil organizada, o direito será caracterizado pelo esforço de estabilizar as relações dos sujeitos; logo, serão estabelecidas normas comuns e valores a serem adotados pelos indivíduos. A partir disto, os sujeitos terão condições materiais de exercer ao grau mais alto as suas potências, assumindo o Estado o papel de compor essas potências, promover encontros, dar limites às tristezas.

Partindo desses princípios, Espinosa assevera que as leis comuns, formadas pelo Estado civil, nada mais serão do que a expressão das relações compostas entre os homens constituintes da multidão. Por conseguinte, a potência dos sujeitos também será 
a expressão da potência da multidão. Tanto mais potência tiver a multidão, tanto mais direitos terão os indivíduos. Veja-se o que diz Negri:

"A multitudo, na paradoxal natureza que exibe, é fundação da democracia na medida em que permite a cada indivíduo singular levar à sociedade, inteiramente, os próprios valores de liberdade. Cada singularidade é fundamental." (NEGRI, 2016, p. 71-72)

A multidão se organizará a partir de direitos comuns, leis e normas de conduta, cujo objetivo é compor relações afetivas entre sujeitos. O direito, sob esta lógica, é uma expressão da multidão, uma vez que proporciona estabilidade para que os homens possam expressar suas potências singulares de forma ampliada. As leis, então, existem para criar condições efetivas para o exercício da potência de agir.

Como já visto, a razão é um esforço contínuo dos homens, que constantemente são guiados pelos desejos. O Estado autônomo não pode, por sua vez, ser orientado para seguir quaisquer ditames que não os da razão, pois, se o fizer, não será capaz de orientar a composição de potências singulares. Isto é, cada um agirá conforme aquilo que melhor lhe convier, ignorando, assim, a busca pelo bem comum.

Dado este fato, o Estado deverá se fundar em instituições, leis e normas dirigidas pela razão. Não se poderá, portanto, confiar ao governante o poder de guiar as instituições, pois, como afirma o filósofo, estes estarão fadados a querer dominar o poder pertencente a multidão. Serão, portanto, as instituiçõesque assegurarão a estabilidade do Estado, seu papel também será o de frear a ambição de domínio do governante, preservando, dessa forma, a potência da multidão.

Em seu Tratado Político, Espinosa trará a questão da participação da multidão no governo. Para o autor, até mesmo em uma monarquia, forma de governo em que a multidão é governada por apenas um indivíduo, é preciso que haja participação popular. Assim, o filósofo propõe a criação de conselhos compostos por cidadãos, os quais deverão agir de forma a limitar o poder do soberano. É proposto, também, que se acabe com a condição de nobreza, sendo esta restrita apenas aos herdeiros do rei.

Quanto ao exército, fundamental para assegurar ao Estado sua soberania, Espinosa assevera que este deve ser formado apenas por cidadãos natos, sem exceções, afastando, com isso, a existência de milícias estrangeiras entre os soldados e evitando, 
dessa feita, que ocorra uma insurgência e o Estado seja destruído. Ademais, o filósofo entende que a terra deve ser de domínio público, não objeto de propriedade privada. Logo, a multidão será dona das terras, permitindo que cada indivíduo faça uso dela gratuitamente, sem a cobrança de impostos em tempos de paz.

Espinosa também tece desenhos para as instituições aristocráticas. O autor entende que o número de patrícios deve ser constantemente proporcional ao de plebeus. "de modo que suas decisões reflitam sempre o interesse público" (STERN, 2009, p. 112). Os cargos administrativos devem ser distribuídos aos plebeus, mantendo-se, assim, as funções e engrenagens do Estado sob o poder da multidão. O que o autor está propondo é a criação de instituições que conservem a potência da multidão. Negri discorre sobre o assunto. Veja-se:

"[...] mesmo que todos os habitantes da cidade participassem da forma aristocrática da gestão, a cidade permaneceria aristocrática, e essa totalidade de participação não a restituiria ao governo absoluto, porque o governo absoluto é um governo baseado não na 'escolha' (ainda que fosse de todos), mas na multitudo, no fundamento da liberdade dos indivíduos singulares que compõem aquela multitudo - portanto, no respeito recíproco das liberdades de cada um." (NEGRI, 2016, p. 72)

Na literatura espinosana, o conceito de democracia é intrínseco (STERN, 2009, p. 113), pois o poder político decorre da potência da multidão. Nesse sentido, o Estado verdadeiramente autônomo é a expressão política da potência coletiva. A potência da multidão, assim como as potências singulares, se exprimirá em sua atualidade, de maneira a estar constantemente construindo a política institucional do Estado. A relação, portanto, entre Estado autônomo e multidão é imanente. Sob esta lógica, Espinosa entende como originário o sistema de governo baseado na democracia.

Para Espinosa, a democracia é a melhor forma de conservar a potência da multidão, de trazer estabilidade ao governo em busca do útil comum e de promover a composição de potências entre semelhantes. A tirania, por sua vez, "é a deformação do Estado" (STERN, 2009, p. 120), pois se sustenta na busca por satisfação de interesses 
privados, levando a multidão ao regime da servidão e proporcionando nada mais do que tristeza entre os sujeitos. Mais uma vez, discorre Negri:

"[...] a democracia devém absolutidade, pois coloca em movimento, a partir de baixo, da igualdade de uma condição natural, todas as potências sociais. Democracia como forma omnino absoluta de governo; isso significa então que não há qualquer alienação do poder, nem em relação a seu exercício, nem em relação à sua formação, [...]. O absoluto é a não alienação, ou melhor, de modo positivo, é a liberação de todas as energias sociais, em um conatus geral de organização da liberdade de todos contínuo, permanente.” (NEGRI, 2016, p. 60-61).

O sujeito, portanto, que constitui a absolutidade da democracia é a multidão. $\mathrm{O}$ Estado que é capaz de reconhecer as singularidades dos indivíduos e suas necessidades, buscando, assim, a formação de direitos comuns, está exercendo a democracia. Nesses casos, a potência da multidão governará o Estado, ao contrário do Estado de obediência servil, que está sob a jurisdição dos afetos de seu governante.

O que marca, então, a organização política servil é a ideia de que aqueles que a compõem são súditos, não cidadãos, como é na democracia. Nesse sentido, os súditos transferem e alienam seus direitos como fundamento da soberania desse Estado servil. Espinosa nega essa ideia de alienação como necessária à soberania do Estado. Para o filósofo, o poder político é imanente da multidão, que se constitui enquanto limite para a razão política (NEGRI, 2016).

Assim, a democracia se demonstra enquanto a forma de governo mais propensa a permitir a convivência pacífica entre as singularidades, sem forçar os sujeitos a agir conforme a vontade de um único governante - o soberano - porque se trata de um Estado capaz promover a composição entre potências, gerando, segundo NEGRI (2016, p. 71), "recíproca tolerância".

A liberdade, por conseguinte, poderá ser experimentada em maiores graus no Estado democrático, pois esta forma de governo permite aos indivíduos, como um todo, viver governados sob o regime da razão, pela busca do bem útil, consequentemente, 
refreando as paixões tristes através da composição de bons encontros, os quais aumentam a potência singular.

É preciso compreender, no entanto, que a política é um processo de ação. Isto é, embora a democracia seja a forma de governo ideal para a experiência da liberdade, esta decorre da dinâmica dos afetos. Neste sentido, é fundamental ao Estado agir, constantemente, de maneira a coibir e refrear afetos que provocam a diminuição da potência do ser e, ao mesmo tempo, deve propiciar bons encontros, que geram paixões alegres e, por decorrência, aumentam a potência singular dos seres. É como propõe Negri:

"A minha conjectura é de que a democracia espinosana [...] deve ser concebida como prática social de singularidades que se entrecruzam em um processo de massa, ou melhor como pietas que forma e constitui as relações recíprocas singulares que se estendem entre a multiplicidade dos sujeitos que constituem a multitudo." (NEGRI, 2016, p. 74)

A partir dessa interpretação, pode-se entender que, na filosofia de Espinosa, o fundamento do Estado não é dominar seu povo, ou fazer com que os homens se tornem servos de seus governantes, na realidade, o Estado tem por princípio combater a servidão, libertar os indivíduos de uma vida servil, fadada ao movimento das paixões tristes. Tanto maior a liberdade proporcionada por um Estado, tanto mais segurança e estabilidade política serão experimentadas pelos sujeitos. Espinosa assevera:

“O fim do Estado, repito, não é fazer os homens passarem de seres racionais a bestas ou autômatos: é fazer com que sua mente e seu corpo exerçam em segurança as respectivas funções, que eles possam usar livremente a razão e que não se digladiem por ódio, cólera ou insídia, nem se manifestem intolerantes uns para com os outros. O verdadeiro fim do Estado é, portanto, a liberdade." $" 11$

\footnotetext{
${ }^{11}$ ESPINOSA, Baruch de. Tratado Teológico Político, XX. In: NEGRI, Antonio. Espinosa Subversivo e outros escritos. Belo Horizonte: Autêntica, 2016. p. 42.
} 
A beleza e a radicalidade da filosofia espinosona incide, justamente, em entender a existência do Estado para a garantia da liberdade, e não para a servidão de seu povo. Não há que se falar, portanto, em antagonismo nos desejos do povo e do Estado, uma vez que a função deste será proporcionar a experiência de maiores graus de liberdade pelos homens, compondo potências, refreando afetos passivos.

A legitimidade, nesse contexto, do governo democrático está, principalmente, no caráter imanente dessa filosofia. Isto é, no fato de que a multidão forma o Estado, que deverá sempre agir conforme a razão, visando criar políticas que criem ambientes propícios para a ampliação das potências singulares que compõem a própria multidão. Esta é, assim, uma relação em que não se abre mão de direitos ou mesmo de liberdade em nome da criação do Estado, o poder não é transcendental, é imanente e, como tal, exprimirá a potência de sua multidão. Sobre a democracia, coloca Negri:

“[...] uma subjetividade que não se detém no desejo de conservação e de aperfeiçoamento do próprio ser, que não se aplana e se fecha em figuras individualistas, mas que coloca o problema do bem e da salvação no comporse e recompor-se, distendendo-se entre todas as potências do mundo: a liberdade, em suma. [...] A democracia possível é a imagem mais íntegra da desutopia da relação absoluta." (NEGRI, 2016, p. 81)

O desejo que será comum a todos os seres será o de perseverar na existência. Esse esforço de existir enquanto aquilo que se é constitui a singularidade das coisas. Assim, afirma-se que a singularidade das coisas se dá na medida da materialidade dos encontros, que promovem a variação na potência de agir. Se esta é ampliada, prevalece a alegria, em detrimento da tristeza, que decorre da diminuição da potência. Compreender as potências é primordial para entender de que forma deve agir o Estado.

Nesse sentido, perseverar na existência nada mais é do que manter sua singularidade diante dos mais diversos encontros, provoquem eles paixões tristes ou alegres. Entretanto, existem limites a essas variações na potência do ser, de modo que é papel do Estado assegurar que as afecções estejam dentro desse limite, que se estabelece 
na medida em que uma afecção transforma o indivíduo em outra coisa, alterando por completo sua singularidade.

É neste sentido, de que os indivíduos estão destinados aos encontros e a variação da potência singular que se entende a sociedade enquanto imanente. Como já afirmado, os seres e suas potências são formados de acordo com a experiência da coletividade. A multidão possui, então, uma "mecânica afetiva" (STERN, 2013, p. 131), que diz respeito a busca pelo desejo comum: de perseveração do ser na existência.

Este é o cerne do Estado, construir condições para a experiência de liberdade, de afetos alegres. O contrário a isso, no Estado onde impera a servidão, esse desejo comum da multidão é ignorado, pois sua finalidade é a satisfação dos interesses privados do governante. Nesse caso, a formação do Estado necessita da obediência de seu povo, que é conquistada através das formas vistas nos capítulos anteriores.

A democracia é, portanto, a oposição a organização política servil. Espinosa concebe o Estado a partir do entendimento de que a forma de governo mais propensa a promover a liberdade e a composição de potências é a democracia e que, além disso, o bem comum a ser buscado é a, acima de tudo, a liberdade. 


\section{Conclusão}

A grande busca dos homens é de sua perserveração na existência. A multidão assim também busca. Os sujeitos se organizam enquanto sociedade civil para que o Estado assuma o papel de instituir políticas que irão garantir essa perseveração. É essa busca pelo bem comum que dá ao Estado caráter legítimo de poder, visto, ainda, que a relação composta entre Estado e multidão é imanente.

O que explica indivíduos abdicarem de sua liberdade e obedecerem a governos autoritários, que visam interesses privados dos governantes é, na visão tanto de La Boétie, quanto de Espinosa, o desejo por preservar a existência. Os dois filósofos terão explicações diferentes para o fenômeno da servidão, mas se assemelham no sentido de que este desejo carece de racionalidade.

Ao constituir uma organização política servil, o indivíduo deixa de ser cidadão e passa a ser súdito. Seu poder de governo torna-se transcendental, não mais imanente. Os súditos não são capazes de enxergar sua servidão, se o fossem, por certo que a combateriam, mas o Estado autoritário se organiza de modo a coibir a experiência da liberdade e, pelos meios apontados no presente trabalho, constroem a ideia do desejo de servir.

O poder político deve ser a expressão da imanência da multidão. Não deve, portanto, representar direitos escusos do tirano em detrimento de seu povo. Como disse Ana Luiza Saramago Stern (2013, p. 297): “é sempre nas mãos da multidão que está a causa imanente do poder político". Nesse sentido, o poder pertence a ninguém menos do que aqueles que compõe e dão origem ao Estado, não podendo estes alienar de seus direitos em nome do que quer que seja.

A função do Estado é ser governado pela razão, uma vez que os seres não o são, sendo muito mais guiados pelos desejos do que por aquilo que a razão entende por bom. As instituições políticas devem, então, ser constituídas tendo por característica a racionalidade. Tanto mais ditadas pela razão forem as ações do Estado, tanto mais serão aquelas de seus cidadãos. É assim que devem ser criadas, portanto, as leis do Estado, diminuindo, por conseguinte, o grau de imprevisibilidade de suas ações e dos encontros.

A organização política que é constituída no seio da liberdade garantirá ao Estado maior segurança política, estando menos propenso a revoltas por parte de seus constituintes. Além disso, a multidão estará menos disposta a sofrer variações em sua 
potência que modifiquem o seu ser. Este é o Estado em que impera a alegria, ao contrário da organização servil.

A servidão é estado de padecimento do ser. Ela é capaz de diminuir a potência não só dos sujeitos, mas também do Estado. Trata-se de uma privação, que impedirá aos homens experimentar maiores graus de liberdades, mais encontros capazes de ampliar suas potências, gerando alegrias. Na organização política servil impera a tristeza, pois o Estado não é capaz de coibir e refrear afetos contrários ao ser.

Essa organização política se funda na tirania, não na liberdade, como Espinosa entende por ser o fundamento do Estado. A servidão não protege os indivíduos, ao contrário, os aprisiona nessa condição de privação e padecimento. Não há nada mais importante, portanto, do que a vocação do Estado para a liberdade. Isso gera a paz entre os cidadãos, garante estabilidade ao governo e cumpre de maneira efetiva com o ideal da organização política: compor potências singulares de modo a ampliá-las.

Nesse sentido, Espinosa é radical e inovador, porque entende o indivíduo, assim como o fez La Boétie, como um ser que nasce para ser livre. É a liberdade que dá humanidade ao homem, que deve se esforçar em sua existência para experimentar cada vez maiores graus dessa liberdade. 


\section{Referências Bibliográficas}

1. BOVE, Laurent. Espinosa e a psicologia social: ensaios de ontologia política e antropogênese. Belo Horizonte: Autêntica, 2010.

2. CHAUÍ, Marilena. Desejo, paixão e ação na Ética de Espinosa. São Paulo: Companhia das Letras, 2011.

3. . Contra a servidão voluntária. Belo Horizonte: Autêntica, 2013.

4. . Anervura do real II. Imanência e liberdade em Espinosa. São Paulo: Companhia das Letras, 2016.

5. . Política em Espinosa. São Paulo: Companhia das Letras, 2003.

6. CLASTRES, Pierre. SANTIAGO, Theo (trad.). A sociedade contra o Estado. São Paulo: Cosacnaify, 2003.

7. . NEVES, Paulo (trad.). Arqueologia da violência - pesquisas de antropologia política. São Paulo: Cosacnaify, 2004.

8. DELEUZE, Gilles. Espinosa e o problema da expressão. São Paulo: Editora 34, 2017.

9. . LINS, Daniel; LINS, Fabien Pascal (trad.). Espinosa filosofia prática. São Paulo: Escuta, 2002.

10. ESPINOSA, Baruch de. Tradução Grupo de Estudos Espinosanos. CHAUÍ, Marilena (coord.). Ética. São Paulo: Editora da Universidade de São Paulo, 2015. 
11. AURÉliO, Diogo Pires (trad.). Tratado Político. São

Paulo: Martins Fontes, 2009.

12. AURÉLIO, Diogo Pires (trad.). Tratado teológicopolítico. São Paulo: Martins Fontes, 2003.

13. LA BOÉTIE, Etiénne de. Discurso sobre a servidão voluntária. São Paulo: Edipro, 2016.

14. MAQUIAVEL, Nicolau. O príncipe. São Paulo: Círculo do Livro, 1989.

15. NEGRI, Antonio. Para uma definição ontológica de multidão. RevistaLugar comum, Rio de Janeiro, n. 19-20, p. 15-26, 2004.

16. - Espinosa Subversivo e outros escritos. Belo Horizonte: Autêntica, 2016.

17. SANTIAGO, Homero. Entre servidão e liberdade, Cadernos Espinosanos, São Paulo, n. XXVI, p. 11-23, 2012.

18. - O que é, quem é a multidão? Disponível em: https://www.outraspalavras.net/outroslivros/o-que-e-quem-e-a-multidao/ Acesso em: 23 out 2018

19. STERN, Ana Luiza Saramago; PILATTI, Adriano. A Imaginação no poder Obediência política e servidão em Espinosa. Rio de Janeiro, 2013, 311p. Tese de Doutorado. Departamento de Direito, Pontifícia Universidade Católica do Rio de Janeiro.

20. ; PILATTI, Adriano. Resistir é obedecer? Resistência e obediência política na filosofia de Baruch Spinosa. Rio de Janeiro, 2009, 150p. Dissertação de Mestrado. Departamento de Direito, Pontifícia Universidade Católica do Rio de Janeiro. 